\title{
SYNTHESIS, CHARACTERIZATION AND ANTIBACTERIAL EVALUATION OF FEW 2, 3-SUBSTITUTED QUINOXALINES
}

\author{
B. JAYACHANDRA REDDY, M.C. SOMASEKHARA REDDY*
}

Department of Sciences, G.P.R. Engg. College (Autonomous), Kurnool -518 002 (A. P.), India. Fax: (91) (8518) 270957; Tel: (91) (8518) 270957

(Received: March 26, 2010 - Accepted: May 13, 2010)

\begin{abstract}
The quinoxaline derivatives (i-v) were synthesized through cyclization-oxidation of $\alpha$ - bromo carbonyl compounds with o-phenyl diamines (7a and 10a) and further coupling at 6-position via Suzuki reaction using $\mathrm{PdCl}_{2}$ (dppf).DCM, ter. $\mathrm{BuNH}_{2}, \mathrm{Na}_{2} \mathrm{CO}_{3}$ in IPA, $\mathrm{H}_{2} \mathrm{O}$ refluxed for $16 \mathrm{~h}$. As the results of antibacterial screening tests done by paper disc method, quinoxaline derivatives (i) and (v) revealed significant inhibition zone on Bacillus spericus and quinoxaline derivatives (iii) and (v) on Escherichia coli cultures.
\end{abstract}

Key words: Quinoxaline, Suzuki Coupling, microwave, Bacillus spericus, Escherichia coli

\section{INTRODUCTION}

Quinoxaline derivatives are an important class of nitrogen containing heterocyclic in medicinal chemistry, have been reported to show biological, including antibacterial activity ${ }^{1}$. For example, quinoxaline is a part of various antibiotics such as echinomycin, levomycin, and actinoleutin that are known to inhibit growth of gram positive bacteria ${ }^{2}$, and are reactive against various transplantable tumors ${ }^{3}$. These have high activity and a broad spectrum of antibacterial activity.

In addition, the frequency of serious nosocomial bacterial and fungal infections is rising due to the use of newer and more powerful antimicrobial agents. As additional new antimicrobial agents are being found, microorganisms become more resistant to existing chemotherapies. Thus, there is continuous need to develop novel antimicrobial compounds that would be effective against these and other pathogens ${ }^{16}$.

In recent times, microwave ${ }^{4},{ }^{5}$ syntheses in organic chemistry is quickly growing. Many organic reactions proceed much faster with higher yields under microwave irradiation compared to conventional heating. It has long been know that molecules undergo excitation with electromagnetic radiation is a technique for microwave synthesis ${ }^{6,7}$. In present synthesis, $\mathrm{AlCl}_{3}$ catalyzes the Friedel-Crafts acylation on $H$-imidazo[1,2-a]pyridine (1a) efficiently under microwave irradiation in solvent free conditions. We synthesized and studied antibacterial activity of few 2,3-substituted quinoxaline derivatives, including those with substituted phenyl ring by replacing halide at 6- position.

\section{EXPERIMENTAL}

All reagents and solvents were purchased from Srinivasa traders, Hyderabad, India. Microwave reactions were carried out using monomode and multi-power biotage sixty microwave instrument. TLC (Pre-coated silica gel $60 \mathrm{~F}_{254}$, Merck) was performed with visualization by UV-light. Melting points were taken in open capillary tubes and corrected with reference to benzoic acid. IR spectra in $\mathrm{KBr}$ pellets were recorded. ${ }^{1} \mathrm{H} \mathrm{NMR}$ recorded in $\mathrm{CDCl}_{3}$ and DMSO-d $\mathrm{d}_{6}$ with $200 \mathrm{MHz}$ instrument as TMS was used as an internal standard. MS spectra were recorded on Agilent 6310 Ion Trap and Shimadzu LCMS (e/z and relative intensity).

1-(H-imidazo[1,2-a]pyridin-3-yl)propan-1-one (3a): The mixture of $\mathrm{H}$-imidazo[1,2-a]pyridine (1a) $(500 \mathrm{mg}, 4.23 \mathrm{mmol})$, propanoic anhydride (2a) $(2.75 \mathrm{~g}, 21.18 \mathrm{mmol})$ and $\mathrm{AlCl}_{3}(1.12 \mathrm{~g}, 8.46 \mathrm{mmol})$ were irradiated in microwave for $20 \mathrm{~min}$ at $100^{\circ} \mathrm{C}$. The reaction mixture was neutralized by using sat. $\mathrm{Na}_{2} \mathrm{CO}_{3}$ and extracted product into ethyl acetate $(25 \mathrm{~mL})$, dried (anhy. $\mathrm{Na}_{2} \mathrm{SO}_{4}$ ) and concentrated by using rotavapour. The crude material was purified through silica gel column chromatography, eluted product by using $2 \% \mathrm{MeOH} / \mathrm{DCM}$ to afford 1-(H-imidazo[1,2-a]pyridin-3-yl)propan-1-one (3a) (352 mg, 47.7\% yield) as a solid. MS (e/z): $175(\mathrm{M}+1)$; $\mathrm{IR} \mathrm{cm}^{-1} 1632(\mathrm{C}=\mathrm{O})$; ${ }^{1}$ HNMR $\left(200 \mathrm{MHz}, \mathrm{CDCl}_{3}\right): \delta 8.56(\mathrm{~d}, J=6.6 \mathrm{~Hz}, 1 \mathrm{H}), 8.63(\mathrm{~s}, 1 \mathrm{H}), 7.84(\mathrm{~d}$, $J=9.2 \mathrm{~Hz}, 1 \mathrm{H}), 7.63(\mathrm{t}, J=6.8 \mathrm{~Hz}, 1 \mathrm{H}), 7.26(\mathrm{t}, J=6.6 \mathrm{~Hz}, 1 \mathrm{H}), 3.04-2.93(\mathrm{q}$, $2 \mathrm{H}), 1.15(\mathrm{t}, J=7.4 \mathrm{~Hz}, 3 \mathrm{H})$.
2-bromo-1-(H-imidazo[1,2-a]pyridin-3-yl)propan-1-one (4a): To a solution of 1-(H-imidazo[1,2-a]pyridin-3-yl)propan-1-one (3a) (300 mg, $1.72 \mathrm{mmol})$ in diethyl ether $(10 \mathrm{~mL})$ and dichloromethane $(2 \mathrm{~mL})$ was added bromine $(325 \mathrm{mg}, 2.06 \mathrm{mmol})$ drop wise at $0^{\circ} \mathrm{C}$. The reaction mixture was warmed to RT, and further stirred for $30 \mathrm{~min}$. The reaction mixture was diluted with diethyl ether $(20 \mathrm{~mL})$. The precipitated solids were filtered and dried by using vacuum to afford 2-bromo-1-(H-imidazo[1,2-a]pyridin-3-yl)propan-1one (4a) (200 mg, 46\% yield) as a pale brown solid. MS (e/z): $254(\mathrm{M}+1)$; IR $\mathrm{cm}^{-1} 1665(\mathrm{C}=\mathrm{O}) ;{ }^{1} \mathrm{HNMR}\left(200 \mathrm{MHz}, \mathrm{CDCl}_{3}\right): \delta 9.82(\mathrm{~d}, J=6.6 \mathrm{~Hz}, 1 \mathrm{H}), 9.24$ $(\mathrm{s}, 1 \mathrm{H}), 8.60(\mathrm{~d}, J=9.2 \mathrm{~Hz}, 1 \mathrm{H}), 8.15(\mathrm{t}, J=6.8 \mathrm{~Hz}, 1 \mathrm{H}), 7.62(\mathrm{t}, J=6.6 \mathrm{~Hz}, 1 \mathrm{H})$, $5.51-5.59(\mathrm{q}, 1 \mathrm{H}), 2.01(\mathrm{~d}, J=7.4 \mathrm{~Hz}, 3 \mathrm{H})$.

6-bromo-3-(H-imidazo[1,2-a]pyridin-3-yl-methylquinoxaline (5a): To a solution of tert-butyl 2-amino-4-bromophenylcarbamate (10a) $(150 \mathrm{mg}$, $0.522 \mathrm{mmol})$ in acetonitrile $(5 \mathrm{~mL})$ were added triethylamine $(132 \mathrm{mg}, 1.305$ $\mathrm{mmol}$ ) and 2-bromo-1-(H-imidazo[1,2-a]pyridin-3-yl)propan-1-one (4a) (132 $\mathrm{mg}, 0.522 \mathrm{mmol}$ ) slowly at RT. The reaction mixture was further stirred for 12 h. Trifluoro acetic acid $(0.5 \mathrm{~mL})$ was added to the above reaction mixture drop wise at RT and stirred for $5 \mathrm{~h}$ at $85^{\circ} \mathrm{C}$. The reaction mixture was concentrated by using rotavapour. The residue was diluted with water and adjusted $\mathrm{pH} \sim 8$ by using Sat. $\mathrm{NaHCO}_{3}$ solution. The precipitated solids were filtered, washed with water and dried under vacuum to afford 6-bromo-3-(H-imidazo[1,2-a] pyridin-3-yl-methylquinoxaline (5a) (101 mg, 56\% yield) as a solid. MS (e/z): $340(\mathrm{M}+1) .{ }^{1} \mathrm{HNMR}\left(200 \mathrm{MHz}, \mathrm{DMSO}_{\mathrm{d}}\right): \delta 9.87(\mathrm{~d}, J=4.2 \mathrm{~Hz}, 1 \mathrm{H}), 8.73-$ $8.71(\mathrm{~m}, 2 \mathrm{H}), 7.99-7.81(\mathrm{~m}, 2 \mathrm{H}), 7.21(\mathrm{~m}, 1 \mathrm{H}), 7.01(\mathrm{t}, J=6 \mathrm{~Hz}, 1 \mathrm{H}), 6.70(\mathrm{~d}$, $J=7.8 \mathrm{~Hz}, 1 \mathrm{H}), 2.99(\mathrm{~s}, 3 \mathrm{H})$.

6-(4-flurophenyl)-3-(H-imidazo[1,2-a]pyridin-3-yl)-2 methylquinoxaline (i): 6-bromo-3-(H-imidazo[1,2-a]pyridin-3-ylmethylquinoxaline (5a) (75 mg, $0.221 \mathrm{mmol}$ ) was dissolved in $i \mathrm{PrOH}-\mathrm{H}_{2} \mathrm{O}$ ( $\mathrm{mL}, 1: 1$ ) and de-oxygenated by bubbling with $\mathrm{N}_{2}$ for $5 \mathrm{~min}$. Then $\mathrm{PdCl}_{2}$ (dppf) DCM (cat), tert-BuNH $(1.8 \mathrm{~mL}), \mathrm{Na}_{2} \mathrm{CO}_{3}(47 \mathrm{mg}, 0.442)$ were added to the reaction mixture at RT. After being stirred for $15 \mathrm{~min}$, 4-fluoro phenylboronic acid $(6 \mathbf{6})(31 \mathrm{mg}, 0.221 \mathrm{mmol})$ was added to the reaction mixture and heated at $100^{\circ} \mathrm{C}$ for $16 \mathrm{~h}$. After the completion, the volatiles were concentrated by using rotavapour. The residue was diluted with water and extracted with EtOAc (3 x $50 \mathrm{~mL}$ ). The combined organic extracts were dried over anhy. $\mathrm{Na}_{2} \mathrm{SO}_{4}$ and concentrated by using rotavapour. The obtained crude material was purified by column chromatography, eluted product by using $1 \% \mathrm{MeOH} / \mathrm{DCM}$ to afford 6-(4-flurophenyl)-3-(H-imidazo[1,2-a]pyridin-3-yl)-2-methylquinoxaline (i) (32 mg, 40\% yield) as a solid. MS (e/z): $355(\mathrm{M}+1) .{ }^{1} \mathbf{H N M R}(200 \mathrm{MHz}$, DMSO-d $): \delta 9.64(\mathrm{~d}, J=7 \mathrm{~Hz}, 1 \mathrm{H}), 8.86(\mathrm{~s}, 1 \mathrm{H}), 8.36(\mathrm{~s}, 1 \mathrm{H}), 8.24(\mathrm{~s}, 2 \mathrm{H})$, $8.09-7.95$ (m, 4H), $7.53(\mathrm{t}, J=6.6 \mathrm{~Hz}, 1 \mathrm{H}), 7.40(\mathrm{t}, J=8.8 \mathrm{~Hz}, 2 \mathrm{H}), 2.98(\mathrm{~s}, 3 \mathrm{H})$.

1,2-dihydro-3-(H-imidazo[1,2-a]pyridine-3-yl)-2-methylquinoxaline (ii): To a solution of 2-bromo-1-(H-imidazo[1,2-a]pyridin-3-yl)propan-1-one (4a) $(100 \mathrm{mg}, 0.395 \mathrm{mmol})$ in acetonitrile $(10 \mathrm{~mL})$ was added benzene-1,2diamine (7a) (43 mg, $0.395 \mathrm{mmol})$ at RT, and further stirred for $4 \mathrm{~h}$. The reaction mixture was concentrated by using rotavapour. The residue was diluted with water and $\mathrm{pH}$ of the solution was adjusted to $\sim 8$ by using sat. $\mathrm{NaHCO}_{3}$. The precipitated solids were filtered, washed with water and dried 
under vacuum to afford 1,2-dihydro-3-(H-imidazo[1,2-a]pyridine-3-yl)-2methylquinoxaline (ii) (40 mg, 39\% yield) as a solid. MS (e/z): $263(\mathrm{M}+1)$; IR cm ${ }^{-1} 3375$ (-NH); ${ }^{1}$ HNMR (200 MHz, DMSO-d $)$ : $\delta 10.26$ (d, $J=7.2 \mathrm{~Hz}, 1$ $\mathrm{H}), 8.71(\mathrm{~s}, 1 \mathrm{H}), 7.96-7.81(\mathrm{~m}, 3 \mathrm{H}), 7.46-7.43(\mathrm{~m}, 1 \mathrm{H}), 7.32(\mathrm{~d}, J=6.8 \mathrm{~Hz}, 1 \mathrm{H})$, $7.01(\mathrm{t}, J=7.8 \mathrm{~Hz}, 1 \mathrm{H}), 6.70(\mathrm{~d}, J=7.8 \mathrm{~Hz}, 2 \mathrm{H}), 6.58(\mathrm{brs}, 1 \mathrm{H}), 4.78-4.73(\mathrm{q}$, $1 \mathrm{H}), 1.17(\mathrm{~d}, J=6.6 \mathrm{~Hz}, 3 \mathrm{H})$.

tert-butyl 4-bromo-2-nitrophenylcarbamate (9a): To a solution of 4-bromo-2-nitrobenzenamine (8a) $(2.5 \mathrm{~g}, 11.5 \mathrm{mmol})$ in DMF $(20 \mathrm{~mL})$ was added $\mathrm{NaH}(60 \%)(690 \mathrm{mg}, 17.25 \mathrm{mmol})$ portion wise at $0^{\circ} \mathrm{C}$. Then added ditertiary butyl dicarbonate $(3 \mathrm{~g}, 13.8 \mathrm{mmol})$ drop wise at $0{ }^{\circ} \mathrm{C}$. The reaction mixture was warmed to RT, and further stirred for $4 \mathrm{~h}$. The reaction mixture was slowly poured into ice-cold water $(50 \mathrm{~mL})$, and further stirred for $1 \mathrm{~h}$. The precipitated solids were filtered, washed with water and dried under vacuum. The crude material was purified through silica gel column chromatography, eluted product by using $1 \%$ ethyl acetate/ hexanes to afford tert-butyl 4-bromo2-nitrophenylcarbamate (9a) (2.1 g, 57\% yield) as yellow solid. MS (e/z): 318 $(\mathrm{M}+1)$; IR cm $\mathrm{cm}^{-1} 3349(-\mathrm{NH}), 1636(\mathrm{C}=\mathrm{O}), 1499(\mathrm{~N}=\mathrm{O})$; ${ }^{1} \mathrm{HNMR}(200 \mathrm{MHz}$, DMSO-d $\left.{ }_{6}\right): \delta 9.60$ (brs, $\left.1 \mathrm{H}\right), 8.51$ (d, $\left.J=8.4 \mathrm{~Hz}, 1 \mathrm{H}\right), 8.32$ (d, $\left.J=2.2 \mathrm{~Hz}, 1 \mathrm{H}\right)$, $7.64(\mathrm{dd}, J=8.6,2.4 \mathrm{~Hz}, 1 \mathrm{H}), 1.59$ (s, 9H).

tert-butyl 2-amino 4-bromophenylcarbamate (10a): To a suspended solution of tert-butyl 4-bromo-2-nitrophenylcarbamate (9a) $(2 \mathrm{~g}, 6.3 \mathrm{mmol})$ in methanol $(20 \mathrm{~mL})$ was added hydrazine hydrate $(6 \mathrm{~mL})$ and ferric chloride (cat) at RT. The reaction mixture was heated to reflux, and further stirred for $3 \mathrm{~h}$. The reaction mixture was filtered through celite bed, washed with ethyl acetate. The filtrate was concentrated by using rotavapour. The crude material was diluted with water and then stirred for $30 \mathrm{~min}$. The precipitated solids were filtered, washed with water and dried under vacuum to afford tert-butyl 2-amino 4-bromophenylcarbamate (10a) (1.4 g, 77\% yield) as a solid. MS (e/z): $288(\mathrm{M}+1)$; IR cm ${ }^{-1} 3410(-\mathrm{NH}), 3345(-\mathrm{NH}), 1686(\mathrm{C}=\mathrm{O}) ;{ }^{1}$ HNMR $\left(200 \mathrm{MHz}, \mathrm{DMSO}-\mathrm{d}_{6}\right): \delta 8.31$ (brs, $\left.1 \mathrm{H}\right), 7.15$ (d, $\left.J=8.4 \mathrm{~Hz}, 1 \mathrm{H}\right), 6.85$ (d, $J=2.2$ $\mathrm{Hz}, 1 \mathrm{H}), 6.64$ (dd, $J=6.2,2.4 \mathrm{~Hz}, 1 \mathrm{H}), 5.18$ (brs, 2H), $1.44(\mathrm{~s}, 9 \mathrm{H})$.

1-(2-methylimidazo[1,2-b]pyridazin-3-yl)ethanone (13a): A mixture of pyridazine-3-amine (11a) $(10 \mathrm{~g}, 105.15 \mathrm{mmol})$ and 3-chloropentane-2,4-dione (12a) $(21.2 \mathrm{~g} ; 157.7 \mathrm{mmol})$ in ethanol $(100 \mathrm{~mL})$ was refluxed at $80^{\circ} \mathrm{C}$ for 24 $\mathrm{h}$. The volatiles were concentrated under reduced pressure. The crude material was purified through silica gel column chromatography, eluted product with $80 \%$ ethylaceate/hexanes to afford 1-(2-methylimidazo[1,2-b]pyridazin-3-yl) ethanone (13a) (7.1 g, 39\% yield) as a solid. MS (e/z): $176(\mathrm{M}+1)$; IR $\mathrm{cm}^{-1}$ $1621(\mathrm{C}=\mathrm{O}) ;{ }^{1} \mathrm{HNMR}\left(200 \mathrm{MHz}, \mathrm{CDCl}_{3}\right): \delta 8.49-8.46(\mathrm{dd}, J=2.6,1.8 \mathrm{~Hz}, 1 \mathrm{H})$, $8.00-7.95$ (dd, $J=7.6,1.6 \mathrm{~Hz}, 1 \mathrm{H}), 7.25-7.18(\mathrm{~m}, 1 \mathrm{H}), 2.83(\mathrm{~s}, 3 \mathrm{H}), 2.77(\mathrm{~s}, 3 \mathrm{H})$

2-bromo-1-(2-methylimidazo[1,2-b]pyridazin-3-yl)ethanone (14a): Synthesis procedure followed similar analogue (4a) (cal. 62\% yield), as a light white solid. MS (e/z): $255(\mathrm{M}+1)$; IR cm $\mathrm{cm}^{-1} 1674(\mathrm{C}=\mathrm{O})$; $1 \mathrm{HNMR}(200 \mathrm{MHz}$, DMSO-d d $_{6}: \delta 8.79$ (d, $\left.J=3 \mathrm{~Hz}, 1 \mathrm{H}\right), 8.28-8.23(\mathrm{dd}, J=9.2,1.4 \mathrm{~Hz}, 1 \mathrm{H}), 7.56-$ $7.49(\mathrm{~m}, 1 \mathrm{H}), 4.95(\mathrm{~s}, 2 \mathrm{H}), 2.64(\mathrm{~s}, 3 \mathrm{H})$

7-bromo-2-(2-methylimidazo[1,2-b]pyridazin-3-ylquinoxaline (15a): Synthesis procedure followed similar analogue (5a) (cal. 60\% yield), as a pale yellow solid. MS $(\mathrm{e} / \mathrm{z}): 341(\mathrm{M}+1) .{ }^{1} \mathbf{H N M R}\left(200 \mathrm{MHz}, \mathrm{DMSO}-\mathrm{d}_{6}\right): \delta 9.89(\mathrm{~d}$ $J=6 \mathrm{~Hz}, 1 \mathrm{H}), 8.72(\mathrm{~d}, J=4.4 \mathrm{~Hz}, 1 \mathrm{H}), 8.40(\mathrm{~s}, 1 \mathrm{H}), 8.24(\mathrm{~d}, J=9.6 \mathrm{~Hz}, 1 \mathrm{H}), 8.08$ (t, $J=8.11,1 \mathrm{H}), 7.43(\mathrm{~m}, 1 \mathrm{H}), 6.61-6.65(\mathrm{~m}, 1 \mathrm{H}), 2.81(\mathrm{~s}, 3 \mathrm{H})$.

7-(4-fluorophenyl)-2-(2-methylimidazo[1,2-b]pyridizin-3-yl) quinoxaline (iii): Synthesis procedure followed similar analogue (i) (cal. $42 \%$ yield), as a pale yellow solid. MS (e/z): $356(\mathrm{M}+1) .{ }^{1}$ HNMR $(200 \mathrm{MHz}$, DMSO-d $\left.{ }_{6}\right): \delta 9.84(\mathrm{~s}, 1 \mathrm{H}), 8.78$ (d, $\left.J=4.2 \mathrm{~Hz}, 1 \mathrm{H}\right), 8.39-8.23$ (m, 4H), 8.04$7.97(\mathrm{~m}, 2 \mathrm{H}), 7.52(\mathrm{~m}, J=9.2,4.6 \mathrm{~Hz}, 1 \mathrm{H}), 7.39(\mathrm{t}, J=9 \mathrm{~Hz}, 2 \mathrm{H}), 2.85(\mathrm{~s}, 3 \mathrm{H})$.

2-(2-methylimidazo[1,2-b]pyridazin-3-yl)quinoxaline (iv): Synthesis procedure followed similar analogue (ii) (cal. $41 \%$ yield), as a solid. MS (e/z): $262(\mathrm{M}+1) .{ }^{1} \mathrm{HNMR}\left(200 \mathrm{MHz}, \mathrm{DMSO}-\mathrm{d}_{\mathrm{f}}\right): \delta 9.82(\mathrm{~s}, 1 \mathrm{H}), 8.69(\mathrm{~d}, J=4.4 \mathrm{~Hz}$, $1 \mathrm{H}), 8.25-8.11(\mathrm{~m}, 3 \mathrm{H}), 7.90-7.86(\mathrm{~m}, 2 \mathrm{H}), 7.41(\mathrm{~m}, 1 \mathrm{H}), 2.81(\mathrm{~s}, 3 \mathrm{H})$.

1-(2-methyl $\boldsymbol{H}$-imidazo $[\mathbf{1}, 2$-a] pyridin-3-yl) ethanone (17a): Synthesis procedure followed similar analogue (13a) (cal. $42 \%$ yield), as a solid. MS (e/z): $175(\mathrm{M}+1) .{ }^{1} \mathbf{H}$ NMR (200 MHz, CDCl $): \delta \square 9.75(\mathrm{~d}, J=8.2 \mathrm{~Hz}, 1 \mathrm{H})$, $7.66(\mathrm{~d}, J=8.8 \mathrm{~Hz}, 1 \mathrm{H}), 7.50(\mathrm{t}, J=7 \mathrm{~Hz}, 1 \mathrm{H}), 7.03(\mathrm{t}, J=7 \mathrm{~Hz}, 1 \mathrm{H}), 2.80(\mathrm{~s}, 3 \mathrm{H})$, $2.63(\mathrm{~s}, 3 \mathrm{H})$.

2-bromo-1-(2-methylH-imidazo[1,2-a]pyridin-3-yl)ethanone (18a): Synthesis procedure followed similar analogue (4a) (cal. $61 \%$ yield), as a pale brown solid. MS (e/z): 255 (M+1). ${ }^{1} \mathbf{H}$ NMR (200 MHz, $\left.\mathbf{C D C l}_{3}+\mathbf{D M S O}-\mathbf{d}_{6}\right)$ : $\delta \square 9.85(\mathrm{~d}, J=8.2 \mathrm{~Hz}, 1 \mathrm{H}), 8.21(\mathrm{~d}, J=8.8 \mathrm{~Hz}, 1 \mathrm{H}), 8.02(\mathrm{t}, J=7 \mathrm{~Hz}, 1 \mathrm{H}), 7.61$ (t, $J=7 \mathrm{~Hz}, 1 \mathrm{H}), 4.45(\mathrm{~s}, 2 \mathrm{H}), 3.05(\mathrm{~s}, 3 \mathrm{H})$.

1,2-dihydro-3-(2-methylH-imidazo[1,2-a]pyridin-3-yl)quinoxaline (v): Synthesis procedure followed similar analogue (ii) (cal. $45 \%$ yield), as a solid. MS (m/z): $263(\mathrm{M}+1)$; IR cm ${ }^{-1} 3389(-\mathrm{NH}) ;{ }^{1} \mathbf{H}$ NMR $(200 \mathbf{~ M H z}$, DMSO-d $)_{6}: \delta \square 10.03(\mathrm{~d}, J=7.0 \mathrm{~Hz}, 1 \mathrm{H}), 7.79-7.66(\mathrm{~m}, 2 \mathrm{H}), 7.28(\mathrm{t}, J=7.2 \mathrm{~Hz}$,
$1 \mathrm{H}), 7.19(\mathrm{~d}, J=7 \mathrm{~Hz}, 1 \mathrm{H}), 6.96(\mathrm{t}, J=6.2 \mathrm{~Hz}, 1 \mathrm{H}), 6.68(\mathrm{t}, J=6 \mathrm{~Hz}, 2 \mathrm{H}), 6.23$ (brs, 1H), 4.37 (s, 2H), 2.68 (s, 3H).

\section{RESULTS AND DISCUSSION}

All the Quinoxaline derivatives (i-v) in this report were synthesized through cyclization-oxidation with o-phenyl diamine analogs, then further synthesized quinoxaline-phenyl substituted compounds (i and iii) were prepared by coupling with 4-fluoro phenyl boronic acid via Suzuki Coupling using $\mathrm{PdCl}_{2}$ (dppf).DCM, tert- $\mathrm{BuNH}_{2}, \mathrm{Na}_{2} \mathrm{CO}_{3}$ in i-PrOH$-\mathrm{H}_{2} \mathrm{O}$ refluxed for $16 \mathrm{~h}$.

A microwave synthesis ${ }^{4,5}$ of Friedel-Crafts acylation ${ }^{4,8}$ on $H$-imidazo[1,2-a] pyridine (1a) by using $\mathrm{AlCl}_{3}$, propanoic anhydride (2a) irradiating in microwave at $100^{\circ} \mathrm{C}$ for $20 \mathrm{~min}$ to afford acylated product (3a) (cal. $48 \%$ yield). The bromination ${ }^{9,10}$ at $\alpha$-carbon of acylated product (3a) using $\mathrm{Br}_{2}$ in diethyl ether and dichloromethane at $0^{\circ} \mathrm{C}-\mathrm{RT}$ for $2 \mathrm{~h}$ to afford bromo compound (4a) (cal. $46 \%$ yield). The alkylation of bromo compound (4a) with N-boc-phenyl diamine (10a) using triethyl amine in acetonitrile at $80^{\circ} \mathrm{C}$ for $12 \mathrm{~h}$, and in situ further cyclization-oxidation carried in situ using trifluoro acetic acid under refluxed condition for $4 \mathrm{~h}$ to afford bromo quinoxaline (5a) (cal. 56\% yield). This compound (5a) further coupled with 4-fluoro phenyl boronic acid (6a) via Suzuki Coupling ${ }^{11,12}$ using $\mathrm{PdCl}_{2}$ (dppf).DCM, ter. $\mathrm{BuNH}_{2}, \mathrm{Na}_{2} \mathrm{CO}_{3}$ in i-PrOH- $\mathrm{H}_{2} \mathrm{O}$ under reflux condition for $16 \mathrm{~h}$ to afford quinoxaline derivative (i) compound (cal. $40 \%$ yield) according to the Scheme-I.

The 1,2-dihydro quinoxaline derivative (ii) was prepared by cyclization ${ }^{12}$, of bromo compound (4a) with o-phenyl diamine (7a) in acetonitrile at RT for $4 \mathrm{~h}$ according to scheme-I.

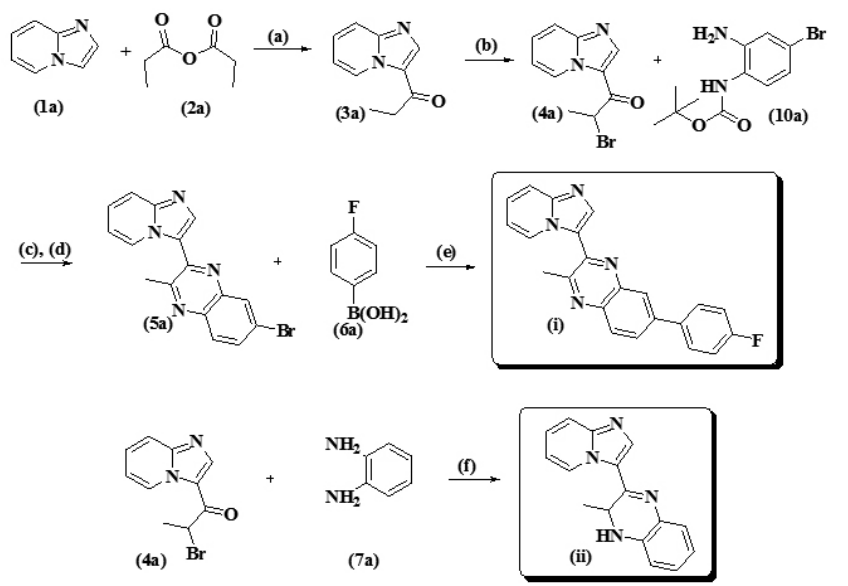

Reagents \& Conditions: (a) $\mathrm{AlCl}_{3}$ microwave, $100^{\circ} \mathrm{C}, 20 \min$ (b) $\mathrm{Br}_{2}, \mathrm{Et}_{2} \mathrm{O}, \mathrm{DCM}, 0^{\circ} \mathrm{C}-\mathrm{rt}, 2 \mathrm{~h}$ (c) $\mathrm{ACN}, \mathrm{rfx}, 12 \mathrm{~h}$ (d) trifluoro acetic acid, 3h (e) PdCl2 (dppf).DCM, tert- $\mathrm{BuNH}_{2}, \mathrm{Na}_{2} \mathrm{CO}_{3}$, iPrOH- $\mathrm{H}_{2} \mathrm{O}, \mathrm{ffx}, 16 \mathrm{~h}$ (f) ACN, RT, 4h

Tert-butyl-2-amino-4-bromophenyl carbamate (10a) was prepared by boc protection of 4-bromo-2-nitrobenzenamine (9a) (cal. 57\% yield), further reduced with hydrazine hydrate, ferric chloride (cat) in methanol refluxed for 3 $\mathrm{h}$ (cal. $77 \%$ yield) according to the Scheme-II.

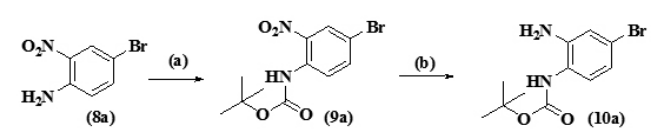

Reagents \& Conditions: (a) $(\mathrm{BOC})_{2} \mathrm{O}, \mathrm{NaH}(60 \%), \mathrm{DMF}, 0^{\circ} \mathrm{C}-\mathrm{RT}, 5 \mathrm{~h}$ (b) $\mathrm{NH}_{2} \mathrm{NH}_{2} \cdot \mathrm{H}_{2} \mathrm{O}$, ferric chloride (cat), MeOH, rf $4 \mathrm{~h}$

The quinoxaline -phenyl derivative (iii) was prepared according to the method describes for preparation of analogue of (i). The intermediate compounds (13a, 14a, 15a) also prepared according to the method describes for preparation of analogue of (3a, $\mathbf{4 a}$ and $\mathbf{5 a}$ ) according to the Scheme-III.

The quinoxaline derivative (iv) prepared by cyclization-oxidation of bromo compound (14a) with o-phenyl diamine (7a) in acetonitrile at RT for 4 $\mathrm{h}$ according to the Scheme-III. 

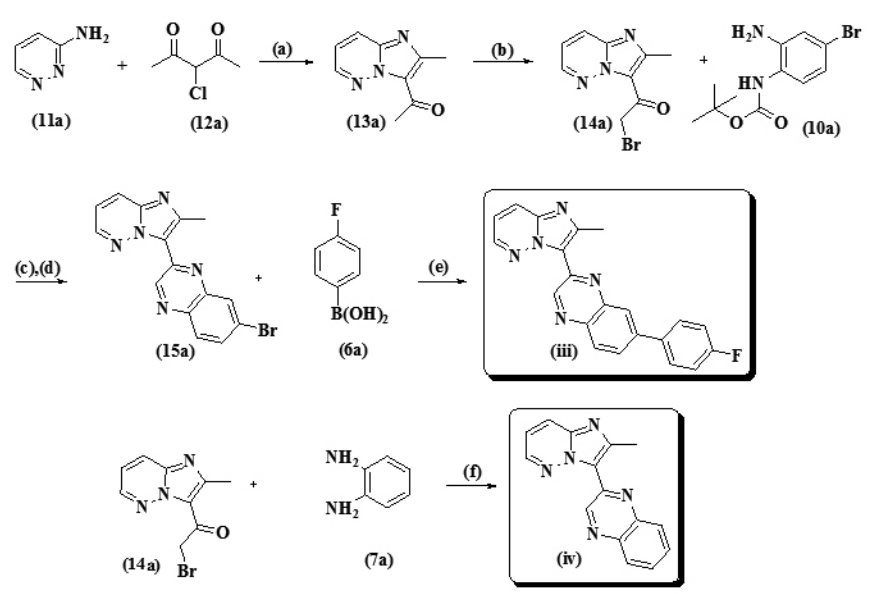

Reagents \& Conditions: (a) $\mathrm{EtOH}, \mathrm{rfx}, 24 \mathrm{~h}$ (b) $\mathrm{Br}_{2}, \mathrm{Et}_{2} \mathrm{O}, \mathrm{DCM}, 0^{\circ} \mathrm{C}-\mathrm{RT}, 2 \mathrm{~h}$ (c) $\mathrm{ACN}, \mathrm{rfx}, 12 \mathrm{~h}$ (d) trifluoro acetic aci, $3 \mathrm{~h}$ (e) $\mathrm{PdCl}_{2}$ (dppf).DCM, tert-BuNH ${ }_{2}, \mathrm{Na}_{2} \mathrm{CO}_{3}, \mathrm{PPOH}-\mathrm{H}_{2} \mathrm{O}, \mathrm{rfx}, 16 \mathrm{~h}$ (f) ACN, RT, 4 h

The 1,2-dihydro quinoxaline derivative (v) prepared by cyclization ${ }^{12}$, of bromo compound (18a) with o-phenyl diamine (7a) in acetonitrile at RT for 4 $\mathrm{h}$. The intermediate compounds (17a and 18a) also prepared according to the method describes for preparation of analogue of ( $\mathbf{3 a}$ and $\mathbf{4 a}$ ) according to the Scheme-IV.

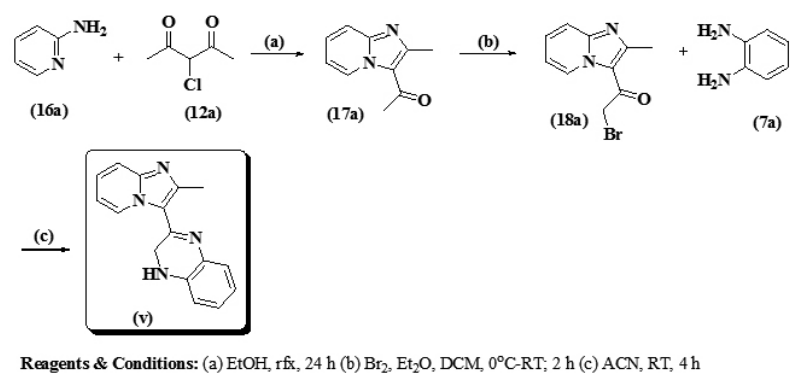

The antibacterial testing was done by the paper disc method ${ }^{13}$. After solidification of media, petriplates inoculated with actively growing culture of Gram positive (Staphylococcis aurius and Bacillus sphericus) and Gram negative (Escherichia coli and Enterobacter aerogens) separately. The organisms were maintained on agar slopes at $4^{\circ} \mathrm{C}$ and sub cultured for $24 \mathrm{~h}$ before use. The bacterial susceptibility was with the agar plate. A standardized inoculums 1-2 $10^{7} \mathrm{cfu} / \mathrm{ml} 0.5 \mathrm{MC}$ Farland standards was introduced onto the surface of sterile agar plate and evenly distributed the inoculums by using a sterile glass spreader. Simultaneously $8 \mathrm{~mm}$ wells were cut from the plate using a sterile cork borer. $100 \mu \mathrm{l}$ of extract at a concentration of $10 \mathrm{mg} / \mathrm{ml}$ was introduced into each well. The agar plates were incubated aerobically at $37^{\circ} \mathrm{C}$. After $24 \mathrm{~h}$ the inhibition zones were measured with a ruler and compared with the control well containing only solvent and $100 \mu$ of extract at a concentration of $10 \mathrm{mg} / \mathrm{ml}$ of streptomycin served as control. All the tests were conducted in triplicates. The data of all the parameters were statistically analyzed and expressed as mean \pm S.D.

After 24 hours the petridishes were checked for growth inhibition zone. The presence of clear zone of growth inhibition around the paper disc indicated the inhibition of growth of organism. The antibacterial activity observed by the length of the zone of inhibition area in $\mathrm{mm}$. Table-A.

As the results of antibacterial screening tests in vitro incorporated in the
Table-A: Antibacterial activity of quinoxaline derivatives (Zone of inhibition in $\mathrm{mm}$ ).

\begin{tabular}{|c|c|c|c|c|}
\hline \multirow{2}{*}{$\begin{array}{c}\text { Titled } \\
\text { compounds }\end{array}$} & \multicolumn{4}{|c|}{ Organisms } \\
\cline { 2 - 5 } & S. aurius & $\begin{array}{c}\text { B. } \\
\text { spericus }\end{array}$ & E. coli & E. aerogens \\
\hline (i) & 4 & 12 & $-v e$ & 2 \\
\hline (ii) & 4 & $-v e$ & $-v e$ & 2 \\
\hline (iii) & $-\mathrm{ve}$ & $-\mathrm{ve}$ & 20 & $-\mathrm{ve}$ \\
\hline (iv) & 2 & $-\mathrm{ve}$ & $-\mathrm{ve}$ & $-\mathrm{ve}$ \\
\hline (v) & $-\mathrm{ve}$ & 12 & 10 & 2 \\
\hline Solvent control & $-\mathrm{ve}$ & $-\mathrm{ve}$ & $-\mathrm{ve}$ & $-\mathrm{ve}$ \\
\hline Streptomycin & 19 & 20 & $-\mathrm{ve}$ & 7 \\
\hline
\end{tabular}

Solvent control - 10\% DMSO; (-ve) -indicates no inhibition zone.

\section{CONCLUSIONS}

Synthesis of some 2,3-substituted quinoxaline derivatives (i-v) were prepared by cyclization-oxidation with o-phenyl diamines and further extended coupling at 6,7-postions by Suzuki coupling successfully. Surprisingly, isolated cyclized products (ii \& v) and cyclization-oxidized product (iv) under similar conditions. All the synthesized compounds were screened for their antibacterial activities. Compounds (i) and (v) revealed better activity on Bacillus spericus and (iii) and (v) on Escherichia coli cultures. The compound (v) showing better activity against both Escherichia coli and Bacillus spericus.

\section{ACKNOWLEDGEMENTS}

The authors wish to thank Principal, Director and Management of G.P.R.Engg.College (Autonomous), Kurnool-518 002 (A.P.), India for their constant encouragement and help. The authors are also thankful to Indian Institute of Chemical Technology (IICT), Hyderabad for spectral analysis and Literature assistance.

\section{REFERENCES}

1. A. J. Cimanis, N. O. Saldabols, L. N. Alekseeva, A. K. Yalynskaya, M. D. Moskaleva, pharmaceutical Chemistry Journal, 11, 1344, (1977).

2. A. Dell, D. H. William, H. R. Morris, G. A. Smith, J. Feeney, G. C. K. Roberts, J. Am. Chem. Soc., 97, 2497, (1975).

3. C. Bailly, S. Echepare, F. Gago, M. J. Warning, Anti-cancer drug Des, 14, 3, 291, (1999).

4. W. Deng, Y. Xu, Q. X. Guo, Chinese Chemical letters, 16, 3, 327, (2005).

5. O. Olayinka, A. Ajani Craig, Obafemi, O. Chinwe, O. lkpo Kolawole, O. Ajanaku Kehinde, Ogunniran, Oladele Oludola James, International Journal of Physical sciences, 4, 156 (2009).

6. F. Pisani, A. Fazio, C. Artesi, M. Russo, R. Trio, G. Oteri, E. Perucca, D. perri, Journal of Neurol Neutosurg Psychiatry, 55, 126, (1992).

7. M. Hayakawa, H. Kaizawa, K. I. Kawaguchi, N. Ishikawa, T. Koizumi, T. Ohishi, M. Yamano, M. Okada, M. Ohta, S. I. Tsukamoto, I. Florence, Raynaud, D. Michael, D. Waterfiledm, P. Parker, P. Workman, Bioorganic \& Medicinal Chemistry, 15, 1, 403, (2007).

8. A. Bensari, N. T. Zaveri, Synthesis, 267-271, (2003).

9. T. Choi, E. Ma, Molecules, 12, 74, (2007).

10. Jr. Melvin, S. Lawrence, venkataramani, Chandrasekar, W0/2009/002534.

11. G. A. Molander, C. R. Bernardi, J. Org. Chem., 67, 8424-8429 (2002).

12. B. Das, K. Venkateswarlu, K. Suneel, A. Majhi, Tetrahedron letters, 48, $31,5371,(2007)$

13. L. Neppi, "In the Experimental chemotherapy", Acadamic Press., New York, 21, 169, (1964).

14. J. S. Fairlamb, A. R. Kapadi, A. F. Lee, Org. Lett., 6, 4435. (2004).

15. C. H. Sridevi, K. Balaji, A. Naidu, R. Sudhakaran, E-journal of Chemistry, 6(3), 866, (2009).

16. J. R. Zgoda, and J. R. Porter, Pharm. Biol., 39(3), 221, (2001). 